\title{
Ecosystem Properties of Urban Land Covers at the Aboveground- Belowground Interface
}

\author{
Loren B. Byrne, ${ }^{1,2,3,4 *}$ Mary Ann Bruns, ${ }^{1,2}$ and Ke Chung Kim ${ }^{1,3}$
}

\begin{abstract}
${ }^{1}$ Intercollege Graduate Degree Program in Ecology, The Pennsylvania State University, University Park, Pennsylvania 16802, USA; ${ }^{2}$ Department of Crop and Soil Sciences, The Pennsylvania State University, University Park, Pennsylvania 16802, USA; ${ }^{3}$ Department of Entomology, The Pennsylvania State University, University Park, Pennsylvania 16802, USA; ${ }^{4}$ Present address: Department of Biology, Marine Biology and Environmental Science, Roger Williams University, Bristol, Rhode Island 02809, USA
\end{abstract}

\begin{abstract}
Understanding of ecological differences among urban land covers can guide the sustainable management of urbanized landscapes for conservation of ecosystem services. The objective of our study was to compare ecosystem properties at the aboveground-belowground interface of three landcover types commonly found in residential landscapes: lawns, bark mulch, and gravel mulch. Using unmowed vegetation as a reference land cover, we measured surface soil variables (to $5 \mathrm{~cm}$ depth), $\mathrm{CO}_{2}$ fluxes, and ground temperatures in experimental field plots within 3 years after their creation. Each land cover had a distinctive set of ecosystem properties. Mulched plots had significantly warmer soil and surface temperatures, wetter soils and faster surface litter decomposition than vegetated plots. Variables associated with soil $\mathrm{C}$ and earthworm numbers were consistently lowest in gravel-covered soils, whereas bark mulch plots had highest earthworm abundances, lowest soil bulk
\end{abstract}

density, and temporally variable soil organic matter dynamics. Compared to unmowed plots, lawns had higher soil carbon, $\mathrm{CO}_{2}$ fluxes, and temperatures but lower earthworm abundances especially during 2005 drought conditions. We conclude that ecosystem properties of the land covers were influenced by the composition, density, and arrangement of materials comprising their aboveground habitat structures. We discuss our results within an ecosystem services framework and suggest that interpretations of our findings depend on in situ urban environmental contexts and landscape management objectives. Future studies of urban land covers, their ecosystem properties and associated ecosystem services are needed to help provide a scientific basis for sustainable urban landscape management.

Key words: urban ecology; lawns; mulch; habitat structure; microclimate; earthworms; soils.
Received 11 March 2008; accepted 23 July 2008; published online 3 September 2008

Electronic supplementary material: The online version of this article (doi:10.1007/s10021-008-9179-3) contains supplementary material, which is available to authorized users.

Loren B. Byrne conceived of the study, performed research, and analyzed data. Loren B. Byrne, M. A. Bruns and K. C. Kim designed the study and wrote the article.

*Corresponding author; e-mail: lbyrne@rwu.edu

\section{INTRODUCTION}

Human-mediated land-cover transformations are major drivers of local and global changes to biodiversity and biogeochemical cycles. Humans alter native ecosystems for many reasons including food production, resource extraction, and inhabitation. Of these, ecologists have studied impacts of the former two more extensively than the latter; thus, less is known about the ecology of environments 
where humans live, that is, urban, suburban, and exurban landscapes. In the continental United States, these urbanized landscapes cover more than 1.4 million $\mathrm{km}^{2}$, are inhabited by over $80 \%$ of the population and continue to expand (Brown and others 2005). Similar patterns are evident worldwide leading to increased scientific and societal interest in understanding the ecology of urbanized ecosystems (Grimm and others 2008).

Urbanized ecosystems are highly spatially heterogeneous due to the variety of land-cover types that humans create in them for many diverse functional and esthetic purposes. Thus, human choices about how to manage the extent, composition (for example, lawns, mulches), and spatial patterns (for example, patch size and arrangement) of urban land covers help shape the emergent structure and function of urbanized ecosystems (Pouyat and others 2006; Baker and others 2007). In turn, urban land-cover patterns influence the ability of urbanized landscapes to provide ecosystem services. For example, high proportions of impervious cover may lead to unfavorable regulation of urban microclimates and stormwater runoff (Grimm and others 2008). Other ecosystem services, such as pest control and carbon sequestration, will also be influenced by land-cover management, but fundamental knowledge of their basic ecology is lacking (Byrne 2007). Additional research is needed to achieve more mechanistic understanding of urban ecological patterns and processes (sensu Shochat and others 2006), especially studies comparing the ecosystem properties of different urban land covers. In turn, such research can guide the sustainable design and management of urbanized landscapes in which ecosystem services are conserved and ecosystem disservices are reduced or mitigated (Palmer and others 2004; Byrne 2006, 2007; McCauley 2006).

Following from this broader context, the objective of our study was to measure fundamental ecosystem properties of three urban land covers (within 3 years after their creation) and to evaluate possible contributions of each land cover to ecosystem services and disservices. The land covers were chosen to represent those commonly created and maintained in residential landscapes (for example, private yards around single-family homes): lawn, bark mulch, and gravel mulch. Lawns cover an estimated $128,000 \mathrm{~km}^{2}$ in the US, an area three times larger than that of irrigated corn (Milesi and others 2005), and may comprise upward of $60 \%$ of land cover in urbanized areas (Kaye and others 2004). Mulches are often applied to ornamental garden patches around lawns because of their esthetic and functional properties. In addition, plots of old-field vegetation were included in this study as a comparative, reference unmanaged land cover.

To meet our objective, a field experiment consisting of replicated plots of the four land cover types was conducted. We expected that the aboveground habitat structure (that is, composition, density and arrangement of the physical material at a location; Byrne 2007) characterizing each land cover would result in a characteristic set of above- and below-ground ecosystem properties for each. Specifically, we hypothesized that the quantity and composition of surface organic matter inputs and structure of the vegetation associated with each land cover would strongly influence ground surface temperatures, physical, chemical, and biological soil characteristics, and carbon (C) fluxes. We chose to focus on these variables at the aboveground-belowground interface because little is currently known about effects of urban landcover management on soil ecology even though soils are critical to regulating many ecosystem services (Byrne 2007). Additional data collected from our field experiment (for arthropod communities, net primary productivity, and $\mathrm{N}$ cycling; Byrne 2006) will be presented elsewhere.

\section{MethodS}

\section{Study Site}

We established experimental land-cover plots at Penn State University's Russell E. Larson Research Farm $\left(40^{\circ} 43^{\prime} \mathrm{N}, 77^{\circ} 55^{\prime} \mathrm{W}, 350 \mathrm{~m}\right.$ elevation) located in Centre County, Pennsylvania (Supplemental online Figure 1). The climate of central Pennsylvania is continental with $975-\mathrm{mm}$ mean annual precipitation and mean monthly temperatures ranging from $3^{\circ} \mathrm{C}$ (January) to $21.6^{\circ} \mathrm{C}$ (July). Soils at the site are shallow, well drained lithic Hapludalfs with clay loam texture formed from limestone residuum (Braker 1981). Land-cover plots were created in a 0.84 ha $(200 \times 42 \mathrm{~m})$ old field that had not been managed (except for oncea-year mowing) for at least the previous 25 years (S. Harkcom, farm manager, personal communication). Prior to creation of experimental plots, vegetation in the field was dominated by the grasses Dactylis glomerata and Poa pratensis.

We chose to conduct this experiment in a rural old field rather than an urbanized environment to maintain control over experimental conditions and remove potentially confounding factors associated with urbanization that could have affected measurements 
(for example, soil removal or compaction). Although there may be limitations in extrapolating our results to more urbanized environments, our study complements those conducted in urbanized settings and generates relevant, needed insights into the basic ecosystem properties of urban land-cover types.

\section{Experimental Design and Land Cover Creation}

The experiment began in April 2003 when four replicate $10 \times 10 \mathrm{~m}$ plots each of four urban land covers (lawn, bark mulch, gravel mulch and unmowed old field vegetation; Supplemental Figure 2) were created in a randomized block design in the old field. All plots were separated from each other and field edges by at least 3-m wide strips of mowed lawn. Although plots were established in 2003, all measurements reported in this article were made in 2004 and 2005; in 2003, research focused on arthropod communities, reported elsewhere (Byrne 2006).

Unmowed vegetation plots did not receive any management inputs throughout the study (200305). Lawn plots were created and maintained with regular mowing (approximately twice per month) with a riding or push rotary mower to keep vegetation height at 5-7 cm. Lawns received no other management inputs and are therefore classified as low-maintenance (Byrne and Bruns 2004). After initiation of mowing, plant composition in the lawn plots quickly became significantly different from the unmowed plots due to colonization by common lawn weeds including Trifolium repens, Taraxacum officinale, and Plantago lanceolata ( $>10 \%$ mean cover for each). In addition, mean cover of D. glomerata decreased in the lawns (to $\sim 7.6 \%$ cover) as compared to unmowed plots ( 29\%). Percent cover of $P$. pratensis remained similar between lawn and unmowed plots ( 30) after initiation of mowing. (Methods of plant cover measurements and additional analyses are provided in Byrne (2006))

Vegetation in plots that were to be mulched was mowed and treated with a single application of the herbicide glyphosate. Dead aboveground vegetation was removed from these plots by gently raking to minimize soil disturbance. (Although root biomass remained in mulched plots, it decomposed quickly (within the first season after plot creation; L. Byrne, personal observation) and thus, its effects on 2004 and 2005 measurements are assumed to be minimal relative to main effects of the land-cover treatments.) Mulches, ordered from local landscaping companies, were placed into the plots and spread by hand-raking to $5-8 \mathrm{~cm}$ depths. Bark mulch was dark brown, finely shredded, mixed hardwood obtained from timber logged in Pennsylvania, but information on the exact species composition and origin was unavailable. Bark mulch decomposed slowly in 2003 and was not reapplied in 2004 . However, fresh bark mulch from the same supplier was applied in April 2005. Gravel mulch was grade 2B light bluish-gray limestone (2-4 mm diameter rocks) that did not degrade and was not reapplied during the study period. Throughout the 2003-05 growing seasons, weeds were removed from the mulched plots by hand or with minimal, targeted glyphosate applications to help control dandelions in several plots.

\section{Soil Characteristics}

Except where otherwise noted, soil measurements were made on one homogenized composite soil sample per plot composed of three randomly collected $2 \mathrm{~cm} \varnothing$ by $5 \mathrm{~cm}$ deep soil sub-samples that were air dried and sieved through a 2-mm mesh screen.

pH was measured once in 2004 and 2005 in a 1:1 (wt/wt) water/soil solution with a Thermo Orion meter (Beverly, MA). Bulk density (BD) was measured in September each year from one randomly collected and oven-dried $\left(110^{\circ} \mathrm{C}\right)$ soil core $(7.5 \varnothing$ by $7.6 \mathrm{~cm}$ ) per plot. Loss on ignition (LOI) soil organic matter (SOM) content was measured on three dates each in 2004 (June, August, September) and 2005 (April, June, September) by burning approximately $10 \mathrm{~g}$ oven dry soil at $450^{\circ} \mathrm{C}$ for $24 \mathrm{~h}$. In addition, total soil $\mathrm{C}$ was analyzed at the end of our study (September 2005) on two sieved (1 mm) and ground soil samples per plot by Penn State's Agricultural Analytical Services using an Elementar Variomax CN analyzer (Hanau, Germany).

Gravimetric soil water content in all the plots was measured using samples collected once or twice weekly from April through September in 2004 and 2005. On each date, three random soil sub-samples were collected from each plot and immediately transported back to the laboratory where their fresh weights were recorded (soils were not homogenized). Soils were oven dried $\left(110^{\circ} \mathrm{C}\right)$ for $24 \mathrm{~h}$ and reweighed. The gravimetric water content of the three sub-samples was averaged to provide one mean value per plot per sampling date.

Soil aggregate stability was measured once at the end of the study period (September 2005) following the wet disruption method described by Kemper and Rosenau (1986). Briefly, three randomly collected soil samples $(5.5 \mathrm{~cm} \varnothing, 5 \mathrm{~cm}$ deep) per 
plot were air dried and soil around the outside of each core (where aggregates could have been crushed during removal) was removed. Remaining soil was broken apart, homogenized (giving one composite sample per plot) and sieved to separate 1-2 mm aggregates. Three $4 \mathrm{~g}$ sub-samples of these aggregates per plot were subjected to wet disruption on a mechanical dunker to measure the weight of stable and unstable aggregate fractions (excluding sand).

Soil microbial biomass carbon (SMB-C) was estimated by the chloroform fumigation-extraction method (Horwath and Paul 1994) on one sieved, composite soil sample per plot (composed of 8-10 random sub-samples) collected in June and July 2004. Briefly, composite soil samples from each plot were divided into six $10 \mathrm{~g}$ sub-samples. Three of these were incubated at room temperature in desiccators with chloroform vapor for 5 days; the other three were incubated without chloroform. After incubation, $\mathrm{C}$ was extracted from the soils with a 5:1 $0.5 \mathrm{M} \mathrm{K}_{2} \mathrm{SO}_{4}$ to soil mixture for one hour with constant shaking and then filtered through \#42 Whatman filters. Carbon content of the filtrate was analyzed using a Shimadzu C analyzer (TOC-5000A, Columbia, Maryland). An index of SMB-C is reported as the untransformed $\mathrm{C}$ "flush," that is, the difference in extracted C between fumigated and unfumigated samples (Fierer and Schimel 2002).

Earthworm abundances were quantified by hand-sorting earthworms twice from one random $25 \times 25 \times 25 \mathrm{~cm}$ soil sample $\left(625 \mathrm{~cm}^{3}\right)$ from each plot (collected at least $1 \mathrm{~m}$ from plot edges) in May, July, and September of 2004 and 2005. All plots were sampled within a 4-day span to minimize confounding effects of changing environmental conditions.

\section{Carbon Fluxes}

$\mathrm{CO}_{2}$ flux was measured from the plots' soils on five dates between May and August 2005 using enclosed static chambers (Holland and others 1999) constructed from opaque PVC pipe coupler bases and lids. (Details of the chamber design and sampling methods are provided by Byrne (2006)) On each sampling date, $15-\mathrm{ml}$ gas samples were collected at $0,15,30$, and $45 \mathrm{~min}$ using $30 \mathrm{ml}$ syringes (ColeParmer, Vernon Hills, Illinois) after trimming vegetation to the ground, removing surface material, and closing the chamber. Samples were immediately transferred into evacuated 12-ml glass Exetainer vials with butyl rubber septa (Labco, High Wycombe, England). Soil temperatures were measured adjacent to all chambers and two soil samples were collected from inside the chamber for measurement of gravimetric soil water. On all dates, samples were collected between 9:00 and 11:00 am and analyzed within $24 \mathrm{~h}$ on a Li-Cor 6262 infrared gas analyzer (IRGA, Lincoln, Nebraska). $\mathrm{CO}_{2}$ flux was calculated as $\mu \mathrm{g} \mathrm{CO}_{2}-\mathrm{C} \mathrm{m}^{-2} \mathrm{~h}^{-1}$ following equations given by Holland and others (1999).

Surface decomposition rates were measured as mass lost from litterbags filled with Quercus alba (white oak) leaves collected in October 2003 (immediately after leaf drop) from two adjacent trees on Penn State's campus. Litterbags $(15 \times$ $20 \mathrm{~cm}$ ) were constructed from 2-mm mesh plastic screen and filled with 3-4 g of oven-dry $\left(55^{\circ} \mathrm{C}\right)$ leaf material. A total of 14 litterbags were placed into each of the 16 experimental plots on April 16, 2004 (224 bags total) by securing them to the ground with wire clips. In 2004, one bag per plot was collected 2 and 4 weeks after placement and then every 4 weeks through October. Monthly collection of one litterbag continued from April through October 2005. All soil and non-oak plant material was carefully removed from litterbags before oven drying $\left(55^{\circ} \mathrm{C}\right)$ and re-weighing them to determine their \% mass lost.

\section{Temperatures}

Ground surface and soil temperatures were measured in each of the 16 plots at 30 min intervals from April 2004 to September 2005 using HOBO four-channel industrial dataloggers (Onset Computer Corp., Pocasset, Massachusetts). One soil temperature probe was placed to $5 \mathrm{~cm}$ depth in the center of each plot. One surface temperature probe was laid on top of the mulch (in mulched plots) or soil (in vegetated plots) in the center of each plot and secured with wire clips. For brevity, only daily maximum and minimum temperatures from two 4-day periods were analyzed for this study and are discussed below to exemplify differences in temperature patterns among the land-cover types. Additional temperature analyses are discussed in Byrne (2006).

\section{Data Analyses}

All data were analyzed for significant $(P \leq 0.05)$ differences in Statistica 6.1 (StatSoft, Tulsa, Oklahoma) using general linear models (GLM) with land cover as the between-subjects factor. Sampling date and/or year were used as within-subjects factors where appropriate (that is, for repeated measures data). Block was included as a between-subjects factor in all initial analyses, but was never significant 
$(P>0.05)$ and is therefore not included in the reported statistics. To meet the assumptions of GLM, earthworm data were square root transformed; untransformed data are presented. Aggregate stability data could not be transformed appropriately and were analyzed using the Kruskal-Wallis nonparametric test. Tukey's honestly significant differences test was used for all pair-wise post-hoc comparisons.

\section{RESUlts \\ Soil Characteristics}

All measured soil variables differed significantly among the land-cover types within just over 2 years following land cover transformations. In general, pair-wise comparisons showed that most soil characteristics in lawn and unmowed plots were similar to each other but differed from those in at least one of the mulch-covered soils (Table 1 , Figure 1). Mean soil $\mathrm{pH}$ across all sampling dates was significantly lower in the vegetated plots than in mulched plots, and the $\mathrm{pH}$ was higher in gravel plots than in bark mulch plots (Table 1). The soil bulk density (averaged over both years) was lower for bark-covered soils (by $>0.1 \mathrm{~g} \mathrm{~cm}^{-3}$ ) than for soils under the other land covers, which did not differ from each other. Differences in soil $\mathrm{pH}$ and $\mathrm{BD}$ across the four land covers were similar for both 2004 and 2005 (data not shown; Byrne 2006).

For all sampling dates, mean $( \pm \mathrm{SE})$ gravimetric soil water content ( $\mathrm{g} \mathrm{H}_{2} \mathrm{O}$ g dry soil ${ }^{-1}$ ) was consistently greater in the mulch-covered than in vegetated soils $\left(\mathrm{F}_{3,12}=36.87, P=0.00\right)$. Bark mulch plots $(0.61 \pm 0.11)$ had significantly wetter soils than all other land covers, and soils under gravel $(0.45 \pm 0.1)$ were wetter than those in lawn $(0.34 \pm 0.05)$ and unmowed $(0.36 \pm 0.05)$ plots. Similar patterns were observed for the means across dates within each year (Table 1). For all land covers, mean soil water content was lower $\left(\mathrm{F}_{1,24}=87.19\right.$, $P=0.00)$ in 2005 than 2004 due to drought conditions (see Byrne 2006 for precipitation data).

Loss-on-ignition SOM under bark mulch was significantly greater than SOM under the other land-cover types in 2004 but was not different from SOM in vegetated plots in 2005 (Table 1). By 2005, gravel-covered soils contained significantly less LOI SOM and total $\mathrm{C}$ than did soils under other land covers. Means of total soil C in lawn and bark plots did not differ but were significantly higher than mean soil $C$ in unmowed plots. Mean SMB-C in both types of vegetated plots was greater than in gravel-covered soils, which had mean SMB-C that did not differ from that of bark plots. Mean \% WSA was approximately 15\% lower in gravel-covered soils than in soils under other land covers, which had similar values (Table 1).

Two genera of European earthworms were collected from the plots: Lumbricus and Apporectodea (K. Szlavecz, personal communication). (Due to challenges of earthworm identification, especially for juveniles that comprised 3/4 of our specimens, we did not quantify individuals at the species level.) Mean earthworm abundances were significantly different among the land covers on all dates with significant year $\times$ land cover and year $\times$ month interactions $(P<0.01$, Figure 1$)$, reflecting different temporal population dynamics among the land covers. Mean earthworm densities were consistently greater in bark mulch plots $\left(>600 \mathrm{~m}^{-2}\right)$ than in other land cover plots on all dates. In 2004, densities were intermediate in the vegetated plots and lowest in the gravel plots on all sampling dates. In 2005, earthworm abundances decreased between May and July in the vegetated and gravel plots. In July and September 2005, mean earthworm numbers were below $25 \mathrm{~m}^{-2}$ in the lawns and gravel plots but remained significantly larger $\left(100-200 \mathrm{~m}^{-2}\right)$ and intermediate in the unmowed plots.

\section{Carbon Fluxes}

Soil $\mathrm{CO}_{2}$ flux was significantly affected by land cover and sampling date with a significant land cover $x$ date interaction (Figure 2). $\mathrm{CO}_{2}$ flux was generally greater in June and July than May and August for all land covers. In May and early June 2005, lawns had higher mean $\mathrm{CO}_{2}$ flux rates, whereas rates from unmowed and bark mulch plots were similar to each other but greater than from gravel plots. In late June, mean $\mathrm{CO}_{2}$ flux rates from lawn and bark mulch plots were similar and greater than from unmowed and gravel plots, which were similar to each other. In July, $\mathrm{CO}_{2}$ flux was significantly higher from bark mulch plots than from unmowed and gravel plots. The latter two land covers had similar rates, which were significantly lower than rates from lawns. In August, lawn and bark mulch soils tended to have higher $\mathrm{CO}_{2}$ flux rates than gravel-covered soils with intermediate rates in unmowed plots. Regression analyses indicated that soil water content and temperature were poor predictors of $\mathrm{CO}_{2}$ flux across all land covers and for each individually $\left(R^{2} \leq 0.05\right.$ for most analyses; data not shown; see Byrne 2006).

Percent mass remaining in oak leaf litterbags differed significantly among the land covers on 8 of 15 sampling dates (Figure 3). After 6 months in the 
field, mean \% mass remaining was approximately $10 \%$ lower from litterbags in the mulch plots than in the vegetated plots. This trend continued through 2005 but with greater variability in decomposition rates within and among the land covers. After 18 months, however, an average of about $30 \%$ more mass had been lost from litterbags in mulch plots as compared to vegetated ones (Figure 3).

\section{Temperatures}

Soil and ground surface temperature patterns differed significantly among the land covers. To exemplify differences in daily temperature fluctuations, data are shown for two 4-day periods (April 22-25 and July 15-18, 2004) (Figure 4). These data illustrate the general pattern seen throughout our study that daytime soil and surface temperature maxima differed significantly among land covers, whereas nighttime minima did not (Figure 4). Mean daytime soil and surface temperatures in mulch plots were significantly warmer (by up to $10-15^{\circ} \mathrm{C}$ ) than those of vegetated plots. On some (but not all) days, surface and soil temperatures under gravel mulch were higher than those under bark mulch, when the latter had temperatures more similar to those of vegetated plots. Daytime maximum surface and soil temperatures on successive days differed among the land covers by as much as 15 and $8^{\circ} \mathrm{C}$, respectively (Figure 4). For all land covers, daytime (11:00-17:00) surface temperatures were often higher than soil temperatures, but soil and surface temperatures converged to similar values overnight (4:00-8:00) (Figure 4).

\section{Discussion}

Little is currently known about mechanistic relationships among the habitat structure of urban land covers, their ecosystem properties and the generation of ecosystem services and disservices (Shochat and others 2006; Byrne 2007; Grimm and others 2008). In the following discussion, we focus the interpretation of our results in the context of how each land cover's habitat structure characteristics affected their ecosystem properties. Although recognizing that our results represent initial responses (within 3 years) to land-cover changes in a nonurban experimental field context, we also make selected preliminary and general comments about the land covers' potential effects on ecosystem services or disservices as a way to catalyze additional questions and studies at a range of scales (that is, plot to region) in actual and older urbanized landscapes. 


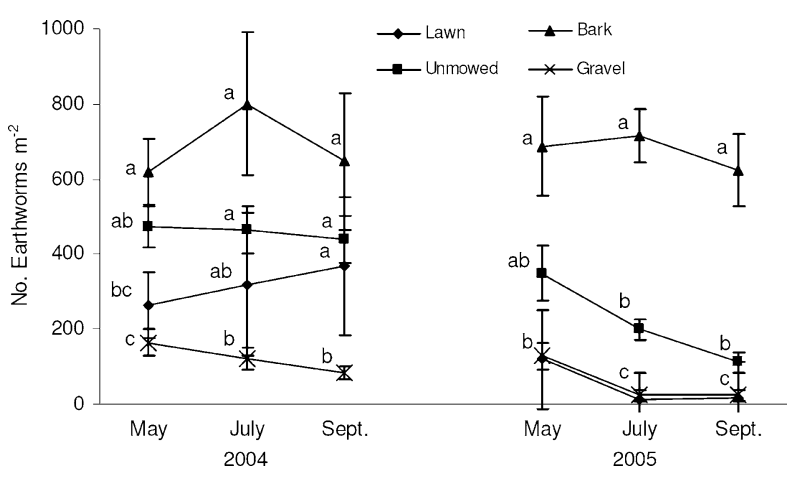

Figure 1. Mean $\left( \pm \mathrm{SE}\right.$ ) number of earthworms $\mathrm{m}^{-2}$ to $25 \mathrm{~cm}$ depth in four urban land cover types in 2004 and 2005. $N=4$ per land cover for all dates. Land $\operatorname{cover}\left(\mathrm{F}_{3,12}=72.5\right)$, month $\left(\mathrm{F}_{2,6}=79.0\right)$ and year $\left(\mathrm{F}_{1,12}=820.8\right)$ main effects were all significant $(P<$ $0.01)$. Two-way interactions were significant $(P<0.001)$ for land cover $\times$ year $\left(\mathrm{F}_{3,12}=147.9\right)$ and month $\times$ year $\left(\mathrm{F}_{2,24}=8.7\right)$ but not land cover $\times$ month $\left(\mathrm{F}_{6,24}=1.5\right.$, $P>0.2)$. The three-way land cover $\times$ month $\times$ year interaction was not significant $\left(\mathrm{F}_{6,24}=10.9, P>0.3\right)$. Means with different letters differ significantly $(P<0.05)$ with Tukey's post-hoc comparisons.

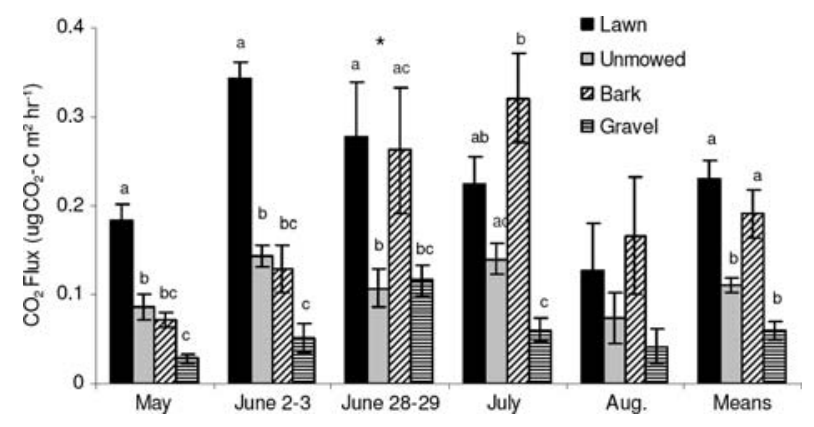

Figure 2. Mean ( $\pm \mathrm{SE}$ ) carbon dioxide flux from soil in four urban land cover types in 2005. $N=4$ for all land covers on all dates. Land cover $\left(\mathrm{F}_{3,12}=19.1\right)$, date $\left(\mathrm{F}_{4,48}=7.9\right)$ and land cover $\times$ date interaction $\left(\mathrm{F}_{12,48}=\right.$ 3.1) were all significant $(P<0.003)$ in repeated measures GLM using five dates. GLM analysis on means across all dates was also significant $\left(\mathrm{F}_{3,12}=19.1\right.$, $P=0.00)$. Means with different letters differ significantly $(P<0.05)$ with Tukey's post-hoc comparisons. * denotes that ladn cover effect for June 28-29 was significant $(P=0.05)$ but Tukey's post-hoc comparisons detected no pair-wise differences among the land covers. Letters shown reflect differences detected with the less conservative LSD post-hoc test.

\section{Soil Characteristics}

To our knowledge, this is the first report of the short-term effects of urban land-cover creation on soil variables in a controlled field experiment. Even though soils were not disturbed physically by

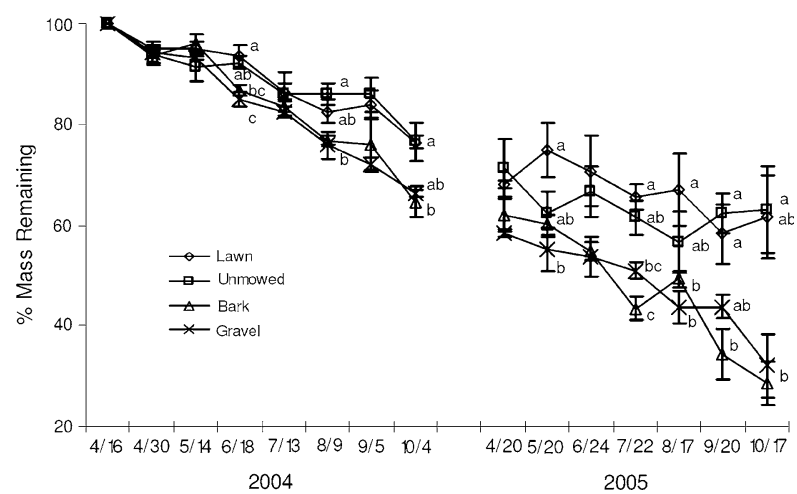

Figure 3. Mean ( \pm SE) percent mass remaining of oak leaves (2004-05) in litterbags from four urban land cover types. $N=4$ for all dates except: $N=3$ for $6 / 24 / 2005$ for gravel, 8/17/05 for unmowed, and 10/17/05 for mulch and $N=2$ for $10 / 17 / 05$ for lawn. Land cover $\left(\mathrm{F}_{3,7}=21.1\right)$, date $\left(\right.$ oak $\left.\mathrm{F}_{13,91}=67.03\right)$ and land cover $\times$ date interactions $\left(\mathrm{F}_{39,91}=1.8\right)$ are significant $(P<0.03)$. Means with different letters differ significantly $(P<0.05)$ with Tukey's post-hoc comparisons.

land-cover transformations, our results indicate that differences in the land covers' aboveground habitat structures affected their belowground ecosystem properties in different ways. For each land cover, a specific set of soil characteristics emerged as a result of physicochemical and biological interactions arising from the composition, density and arrangement of surface materials and presence or absence of vegetation.

Soil Water Content. Differences in soil water content among the land covers have two, perhaps intuitive, co-varying explanations: (1) reduced evaporation in mulched plots due to thick, dense barriers of surface materials; and (2) greater removal of soil water from vegetated plots due to plant transpiration. Bark mulch retained soil moisture more effectively than gravel (possibly due to higher soil temperatures under gravel, Figure 4; see below), a potentially useful insight for management of landscapes (for example, ornamental gardens) in which soil moisture retention is a focal ecosystem service. Because plants were absent from mulched plots, they did not exactly mimic realworld mulched gardens in which horticultural plants would take up some water. However, our observations, combined with those of Scharenbroch and others (2005) who observed higher soil water content in mulch-covered soils as compared to lawns, support the conclusion that management of aboveground habitat structure is likely to be a key local-scale driver (alongside others) of soil moisture patterns across urbanized landscapes. 

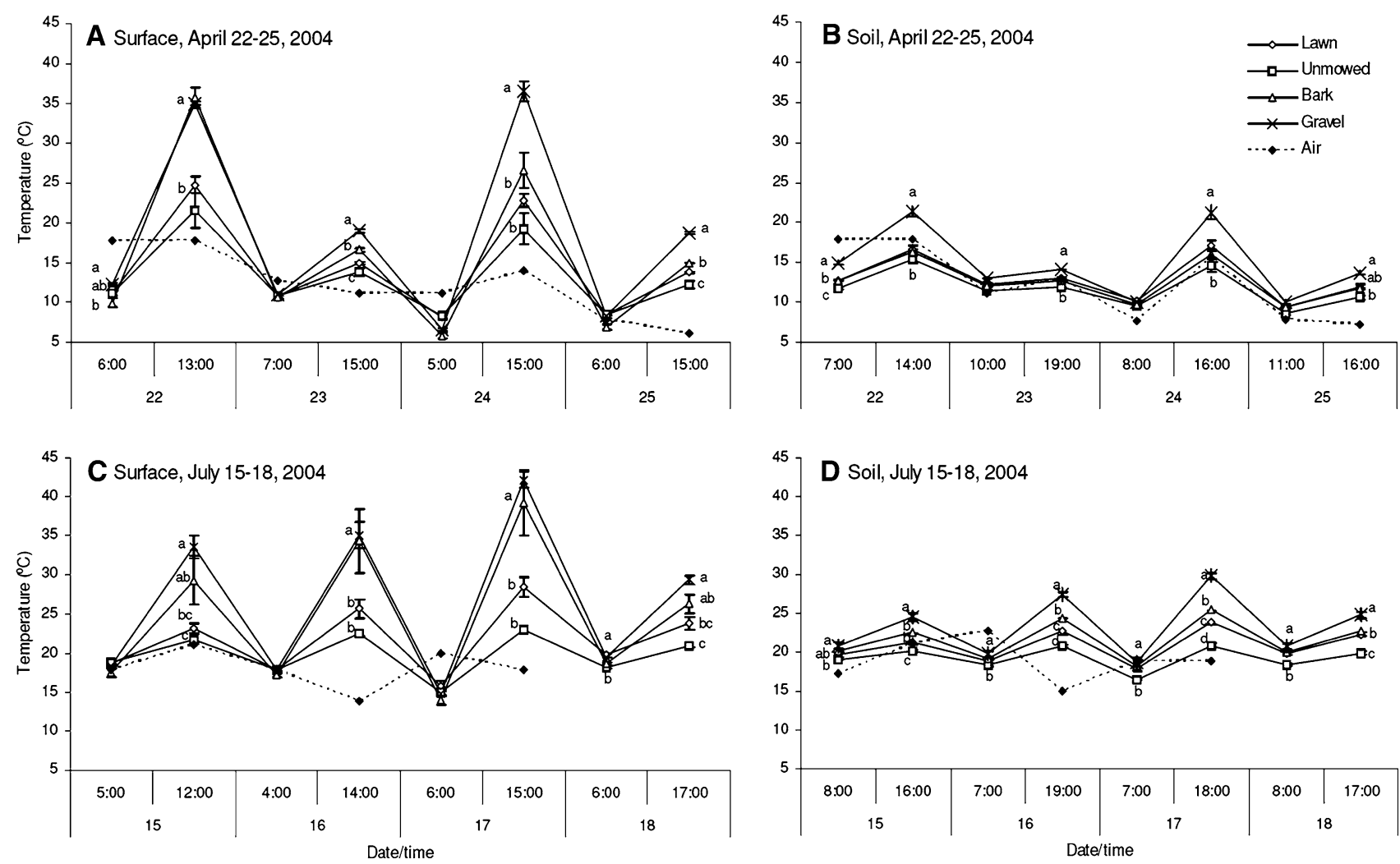

Figure 4. Daily mean (+ SE) maximum and minimum surface and soil temperatures in four urban land cover types and air temperature over four successive days. (A) Surface temperatures for April 22-25, 2004. (B) Soil temperatures (5 cm depth) for April 22-25, 2004. (C) Surface temperatures for July 15-18, 2004. (D) Soil temperatures for July 15-18, 2004. Data points are means of four replicated plots per land cover except for bark, which had only three replicates for April surface temperatures and July surface and soil temperatures. SE bars are generally small (range of 0 to 4.2 ) and therefore not visible at all data points. GLM analyses showed significant effects of land cover, time of day (day or night), date and all their interactions $(P<0.01)$ for all analyses. Means with different letters differ significantly $(P<0.05)$ with Tukey's posthoc comparisons.

Soil Carbon. The management of aboveground habitat structure caused differences in the quantity and quality $(\mathrm{C}: \mathrm{N})$ of soil $\mathrm{C}$ inputs among the land covers. The limestone gravel mulch plots uniquely received high inputs of $\mathrm{CaCO}_{3}$, which significantly increased soil $\mathrm{pH}$ within 2 years. The reductions of LOI SOM, total soil C, and SMB-C in gravel plots (as compared to reference unmowed plots; Table 1) were not surprising given a lack of OM inputs and the higher soil temperatures (Figure 4) and water contents (Table 1) which likely stimulated microbial mineralization of belowground residual $\mathrm{C}$ following land-cover transformation (Raich and Tufekcioglu 2000). Soil organic matter reductions under gravel mulch, in combination with loss of live plant roots, fewer earthworms (Figure 1) and lower microbial biomass (Table 1), probably led to the significantly lower \% WSA in these soils because these variables help maintain soil aggregates (Pulleman and others 2005). In turn, additional losses of SOM and C from gravel-covered soils would have been likely as microbes began to mineralize that which was once protected in aggregates (Table 1) (Bossuyt and others 2005). These rapid changes in soil $\mathrm{C}$ pools under gravel suggest that land-cover management practices that reduce OM inputs but do not disturb soils directly (for example, inorganic mulching, paving) may promote local-scale ecosystem disservices (for example, reduced soil fertility, net flux of $\mathrm{C}$ to the atmosphere).

In bark mulch plots, inputs of low quality detritus (that is, C:N of 123; Byrne 2006) were expected to result in markedly different SOM properties, especially as compared to vegetated plots. Although some differences were observed (for example, LOI SOM in 2004 and soil C in 2005; Table 1), no clear patterns emerged for the effects of bark mulch on SOM-related variables. Although the warmer, wetter soil conditions under the bark mulch (Fig- 
ure 3, Table 1) could have been expected to promote higher microbial activity and biomass than vegetated plots, the slightly lower mean SMB-C levels observed (Table 1) may indicate microbial Nlimitation due to the mulch's high $\mathrm{C}: \mathrm{N}$ ratio (Bossuyt and others 2005). This is supported by observations of very low and sometimes net negative $\mathrm{N}$ mineralization rates in the bark-covered soils (Byrne 2006). Furthermore, higher microbial activity (including on the mulch where high fungal densities were seen; L. Byrne, personal observation) could have increased $\mathrm{C}$ mineralization rates in the soil (Figure 2), thus preventing $\mathrm{C}$ accumulation. High earthworm abundances in bark plots (Figure 1) could also have affected their soil C. Previous studies showed that earthworms can contribute to both the buildup and loss of SOM because their casts, respectively, form stable aggregates that protect $C$ (Pulleman and others 2005) and provide hotspots where microbes mineralize C (Burtelow and others 1998; Borken and others 2000). Additionally, the application of fresh mulch in April 2005 may have stimulated microbial activity and higher decomposition rates (that is, a "priming effect"; Fontaine and others 2004), as supported by the decrease in LOI-SOM observed between 2004 and 2005 (Table 1). Although the bark mulch itself had a high C:N, decomposed, dissolved organic molecules with lower C:N could have leached or been incorporated by earthworms into the soil, promoting microbial activity and preventing expected soil $\mathrm{C}$ accumulations (Lajtha and others 2005). Evidence for the incorporation of bark-derived material into the soil is supported by an observed increase in the bark-covered soils' $\mathrm{pH}$ (7.2) to a value more similar to that of the mulch ( 7.45; Byrne 2006). Although observations are limited to 3 years, longer-term increases in soil OM and $\mathrm{C}$ under bark mulch are possible as suggested by the slight increase in total $\mathrm{C}$ in bark soils (compared to unmowed plots) by the end of the study (Table 1). This compares with findings from a recent study of soils covered with bark mulch for 15 years, in which no SOM accumulation was observed, suggesting that degradable $C$ inputs had become depleted or were undetectable (Scharenbroch and others 2005). Given the widespread use of bark mulches in urbanized landscapes, future work is needed to investigate how use of this land cover at fine scales potentially impacts the emergence of ecosystem services (for example, soil $\mathrm{C}$ sequestration) and disservices (for example, $\mathrm{N}$ immobilization) at larger scales (Pouyat and others 2006).

Lack of significant differences for most soil variables between lawn and unmowed plots (Table 1) suggests that mowing alone does not greatly alter most belowground ecosystem properties. However, total soil $\mathrm{C}$ increased in lawns by approximately $1 / 3$ after 3 years, indicating that initiation of mowing altered belowground $C$ dynamics, certainly due, in part, to inputs of rapidly decaying grass clippings onto the soil. Previous studies of lawn $\mathrm{C}$ dynamics indicate that turfgrass land cover promoted belowground $\mathrm{C}$ accumulation over time (Qian and Follett 2002; Milesi and others 2005) and that lawns had larger surface soil C pools than under unmanaged herbaceous vegetation (Dickenson and Polwart 1982; Byrne and Bruns 2004; Kaye and others 2005; Golubiewski 2006). However, with so few studies comparing lawn $\mathrm{C}$ dynamics to those of other land covers (especially native ones) to assess relative C storage capacity, whether or not lawns actually provide the ecosystem service of higher soil C storage remains an unanswered question in need of future investigations, especially long-term ones (also see " $\mathrm{CO}_{2}$ Flux" section below).

Earthworm Abundance. The range of earthworm densities observed in our plots is similar to that reported for an old field in New York (Shakir and Dindal 1997) and lawns in Idaho (Smetak and others 2007) and the Czech Republic (Pizl and Schlaghamersky 2007). In addition, previous studies of earthworms in urbanized ecosystems have found them to be more abundant in urban than rural forests (for example, Szlavecz and others 2006). We found no previous reports comparing earthworm abundances under different types of urban land cover. Thus, our results provide several insights into how the habitat structural characteristics of urban land covers impact earthworms via the interactive effects of three soil variables known to affect earthworm survival and reproduction: OM, moisture, and temperature (Curry 2004). First, low OM inputs, and thus low food supply, can limit earthworm numbers as demonstrated by their consistently low abundances in gravel plots throughout our study (Figure 1). Even if soil OM is available however, low soil moisture can negatively affect earthworm densities (at least in the top $25 \mathrm{~cm}$ of soil focused on here) as supported by the relationship between lower soil moisture (Table 1) and lower earthworm numbers in the vegetated plots in 2005 versus 2004 (Figure 1). The importance of soil moisture for earthworms is also shown by their consistently higher numbers, especially in 2005, in the wetter soils of bark mulch plots (which, in turn, also explains the reduced soil bulk density observed under this land cover; Table 1). 
Third, as suggested by Curry (2004), the maximum tolerable soil temperature range for temperate earthworms is most likely $25-30^{\circ} \mathrm{C}$. This is supported by the observation that the highest soil temperatures recorded during this study in lawns $\left(28^{\circ} \mathrm{C}\right)$ and gravel $\left(31^{\circ} \mathrm{C}\right)$ plots (Byrne 2006) occurred concurrently (July 2005) with the lowest earthworm numbers (Figure 1). At this sampling date, however, earthworms were significantly more abundant and daytime soil temperatures were on average cooler in unmowed than lawns and gravel plots (Byrne 2006). Unlike data from 2004, significant differences between lawn and unmowed earthworm populations in 2005 suggest that higher average soil temperatures in lawns did not affect earthworms until soil moisture was reduced. In contrast, the warmer, wetter soil conditions may have allowed earthworm populations to increase and remain large under bark mulch. These patterns emphasize the importance of examining multiple, interactive effects of a land cover's habitat-structural characteristics on spatiotemporal patterns of earthworms in future studies.

\section{Carbon Dynamics}

$\mathrm{CO}_{2}$ Flux. Previous field studies found $\mathrm{CO}_{2}$ flux rates from lawns to be several orders of magnitude greater than fluxes from native desert (Green and Oleksyszyn 2002) and shrubgrass steppe habitats (Kaye and others 2005). In a comparison of lawns and bark mulched soils of different ages, Scharenbroch and others (2005) observed in laboratory measurements that soils recently covered with bark mulch tended to have higher $\mathrm{C}$ mineralization rates, although no clear differences were detected between bark-covered and lawn soils. Because few studies have compared $\mathrm{C}$ fluxes among different urban land-cover types (Byrne 2007), our results provide new insights into the differential effects of urban land covers on soil $\mathrm{CO}_{2}$ production.

Two factors probably contributed simultaneously to greater $\mathrm{CO}_{2}$ production in lawns than unmowed plots (Figure 2): (1) higher root density and (2) inputs of high quality (that is, low C:N) mowed clippings. Although we did not measure root biomass, plant density was significantly higher in lawns (Byrne 2006), which would have led to greater $\mathrm{CO}_{2}$ production from denser root growth. Simultaneously, heterotrophic respiration would have been stimulated by additional $C$ inputs from root exudation (Landi and others 2006) and from quickly decomposing mowed clippings (Byrne 2006; Shi and others 2006). If found to be a general pattern over time and space, greater $\mathrm{CO}_{2}$ flux from lawns has implications for reassessing the contribution of lawns to regional C cycles (Kaye and others 2004, 2005; Milesi and others 2005) and whether their ecosystem service value for C turnover and storage is as high as that of unmowed (or even less mowed) vegetation within different biomes (Qian and Follett 2002; Golubiewski 2006).

In contrast to the vegetated plots, $\mathrm{CO}_{2}$ production in the mulched plots was driven solely by heterotrophic respiration due to absence of plants. Even without autotrophic soil respiration, mulched soils might be expected to have had similar or higher $\mathrm{CO}_{2}$ flux rates as vegetated soils due to consistently warmer and wetter soils providing favorable conditions for microbes. However, in this study microbial activity may have been limited in gravel and bark plots by low $\mathrm{C}$ and $\mathrm{N}$ availability, respectively, thus limiting $\mathrm{CO}_{2}$ production (Raich and Tufekcioglu 2000). Across all sampling dates, gravel soils had the lowest mean $\mathrm{CO}_{2}$ flux rates (Figure 2) certainly due to absence of OM inputs and reductions in soil $\mathrm{C}$ (Table 1). However, detection of $\mathrm{CO}_{2}$ flux and SMB-C in gravel plots provides evidence that favorable conditions and residual in situ $C$ supported some heterotrophic soil respiration. Although $\mathrm{C}$ was not limiting in bark mulch plots due to large OM inputs, higher microbial $\mathrm{CO}_{2}$ production may have been limited by $\mathrm{N}$ availability as microbes immobilized $\mathrm{N}$ while decomposing low quality, bark-derived OM (Byrne 2006; Landi and others 2006). Interestingly, $\mathrm{CO}_{2}$ flux from bark-covered soils exhibited a unique temporal pattern with higher rates in late June and July (Figure 2) following application of new mulch in April 2005. A plausible explanation for this is that microbial activity was stimulated by a flush of labile, dissolved OM into the soil due to dense fungal colonies decomposing mulch aboveground (L. Byrne, personal observation). Additional studies are needed to evaluate whether patterns seen in our study occur more widely and how mulches can best be used to promote desired ecosystem services (for example, moisture retention, weed suppression) while limiting their generation of ecosystem disservices (for example, unfavorable effects on $\mathrm{C}$ and $\mathrm{N}$ cycling and soil biota).

Surface Litter Decomposition. Litterbag studies in urban forests showed that surrounding urbanization impacted forest-floor leaf litter decomposition rates (Pouyat and Carreiro 2003; Pavao-Zuckerman and Coleman 2005). However, decomposition patterns in other urban land covers have not been previously reported. Results from our litterbag measurements (Figure 3) show that mass loss rates of aboveground litter were greater in mulches and 
similar to or lower in vegetated land covers than those reported for urban forests (Pouyat and Carreiro 2003; Pavao-Zuckerman and Coleman 2005). We hypothesize that differences in decomposition among our land covers were affected by interactions among their microclimate, detritus layers and biota. Microclimate is known to influence decomposition with higher temperatures and humidity promoting faster decay (for example, Pouyat and Carreiro 2003). In our study, higher surface temperatures in bark and gravel plots (Figure 4) were associated with greater decomposition after 4 and 18 months. However, warmer temperatures may have dried out litterbags more often in the mulch plots, which may have limited microbially driven decay in them. Alternatively therefore, decomposition in mulched plots may have been affected more by abiotic decomposition through greater UV radiation exposure because litterbags on mulches were not shaded by vegetation (Gallo and others 2006). Faster decomposition in mulches could also be attributed to higher colonization of litterbags by detritivorous invertebrates (Vossbrink and others 1979) due to lower densities of palatable surface OM in mulch plots (that is, litterbags were islands of more favorable habitat). Similarly, decomposition in vegetated plots may have been lower because they contained grass litter that may have been preferred by some detritivores, which would have then been less likely to consume leaves in the litterbags. Although this study was not designed to assess mechanistic relationships between decomposition and land cover, our results suggest how a range of variables influenced by the habitat structure characteristics of a land cover might interact to impact the ecosystem properties within it (sensu Byrne 2007).

\section{Temperatures}

As discussed above, some differences in measured variables among the land covers are partially explained by differences in their above- and belowground temperatures. In turn, variation in temperatures among them can be explained by the different thermal properties (that is, absorption, storage, and re-radiation of solar energy) of their respective habitat structure (Gieger and others 2003; Mueller and Day 2005). Thus, greater capacity of dark-colored bark and mineral gravel mulches to absorb solar radiation resulted in higher (by up to $15^{\circ} \mathrm{C}$ ) daytime surface temperatures (that is, "micro-urban heat islands") in mulched than vegetated plots (Figures 4A, C; also see Byrne 2006). In addition, this difference was certainly enhanced by dissipation of heat through greater evapotranspiration in vegetated plots. In unmowed plots, shading by taller vegetation explains its slightly cooler ground surface temperatures as compared to lawns (Figure 4). That temperature differences were seen only during the daytime and that daily temperature fluctuation patterns were similar among land covers both reflect the importance of solar radiation as a driver of temporal microclimate patterns in all land covers. Similar fine-scale spatiotemporal relationships between urban land covers and microclimates were observed in the southwestern US with differential effects on ornamental plant physiology and growth also observed among land covers (Montague and Kjelgren 2004; Mueller and Day 2005). Thus, regulation of fine-scale urban microclimate patterns by land covers can be viewed as an important ecosystem service or disservice (depending on management and environmental context) that impacts ornamental vegetation along with nutrient cycling, pests and even human well-being (Baker and others 2007).

Finally, we comment briefly on observed relationships between above- and belowground temperatures. In general, temporal soil temperature fluctuations can be expected to mimic those of surface temperatures (Gieger and others 2003), a pattern seen in our data (Figure 4) with differences in magnitude attributable to insulating properties of aboveground habitat structure, as seen in previous studies (reviewed in Byrne 2007). Surprisingly however, soils under bark mulch did not reach the same temperatures as gravel-covered soils even though these land covers often exhibited similar surface temperatures. This pattern has two, perhaps interactive, explanations. First, inorganic materials can generally transfer more heat energy into soil than organic materials, as observed by Montague and Kjelgren (2004) and Mueller and Day (2005). Second, the significantly wetter bark-covered soils probably required higher thermal energy inputs to reach the same temperature as gravel-covered soils (Gieger and others 2003). It is not clear what the relative contributions of these two mechanisms might have been in this study, but these results highlight an additional example of how aboveground habitat structure can mediate an ecologically important belowground ecosystem property.

\section{ConClusions}

As urbanized ecosystems and populations continue to expand worldwide, demand for information about their basic ecology is also increasing. Thus, 
ecologists are challenged to generate data about the ecosystem properties and services of uniquely urban land covers (Palmer and others 2004; Byrne 2007; Grimm and others 2008). The study reported here represents a small step toward meeting this need.

Collectively, the results of our study indicate that the aboveground habitat structure characteristics (that is, composition, arrangement, and density of matter) of each land cover interacted to create a distinctive set of ecosystem properties for each. Such observations have applied implications for interpreting and comparing different land covers' contributions to local-scale ecosystem services and disservices. For example, although it has been suggested that lawns sequester $\mathrm{C}$ over time (Table 1, Qian and Follett 2002), we (Figure 2) and others (for example, Kaye and others 2005) observed that they had higher $\mathrm{CO}_{2}$ production rates than unmanaged grasslands, which in comparison is an ecosystem disservice because of the negative effects of increasing atmospheric $\mathrm{CO}_{2}$ on global climate. As another example, higher soil moisture retention by mulches could be viewed as an ecosystem service in gardens; however, their potential to generate extremely warm "miniurban heat islands" in sunny locations may be interpreted as an ecosystem disservice if this negatively affects ornamental plants (Mueller and Day 2005). Other such contrasting interpretations could be made for the differential effects of land covers on earthworms (Figure 1), SOM dynamics (Table 1), N cycling and ground arthropod communities (Byrne 2006).

The above points briefly exemplify the variety of interpretations that can be made about how the ecosystem properties associated with a given urban land cover translate into ecosystem services or disservices. Given this and the variety of land uses and functions that humans desire in urbanized landscapes, we conclude that the interpretation of a land cover's ecosystem properties in terms of ecosystem services or disservices are highly dependent on the environmental context and management objectives for a specific location. Thus, a future challenge for creating more sustainable urbanized ecosystems may be development of general recommendations about how urbanized landscapes should be designed and managed to maximize ecosystem services while minimizing ecosystem disservices. Efforts to meet this challenge will be facilitated by additional studies that describe multivariate sets of ecosystem properties of common urban land covers in actual urban areas and that scale-up plot-scale results to regional patterns. In addition, investigations such as this one about mechanistic relationships among ecosystem properties of urban land covers and their associated ecosystem services will strengthen the scientific basis for developing urban landscape design and management guidelines that can help direct the creation of more sustainable urbanized ecosystems (Baker and others 2007; Byrne 2007; Grimm and others 2008).

\section{ACKNOWLEDGMENTS}

We thank Curt Dell and Ron Wasco for their help with analyses and use of their instrumentation; Julie Bowdle for her aggregate stability work; and Laura Perrin, Wayne Lehman, Matt McCoy, and Jen Lundy for laboratory and field assistance. Jason Rohr provided consultation with statistical analyses and Kathy Szlavecz provided help in earthworm identification. Comments from Peter Groffman and two anonymous reviewers improved the manuscript. Financial support was provided by an NSF Dissertation Improvement Grant (DEB 0411527), the Pennsylvania NASA Space Grant Consortium, the Penn State Center for Environmental Chemistry, and the Penn State Departments of Crop and Soil Sciences and Entomology.

\section{REFERENCES}

Baker L, Brazel A, Byrne L, Felson A, Grove M, Hill H, Nelson KC, Walker J, Shandas V. 2007. Effects of human choices on characteristics of urban ecosystems. Bull Ecol Soc Am October:404-9.

Borken W, Grundel S, Beese F. 2000. Potential contribution of Lumbricus terrestris L. to carbon dioxide, methane and nitrous oxide fluxes from a forest soil. Biol Fertil Soils 32:142-8.

Bossuyt H, Six J, Hendrix PF. 2005. Protection of soil carbon by microaggregates within earthworm casts. Soil Biol Biochem $37: 251-8$

Braker WL. 1981. Soil survey of centre county, pennsylvania. Washington, DC: USDA-SCS.

Brown DG, Johnson KM, Loveland TR, Theobald DM. 2005. Rural land-use trends in the coterminous United States, 19502000. Ecol Appl 15:1851-63.

Burtelow AE, Bohlen PJ, Groffman PM. 1998. Influence of exotic earthworm invasion on soil organic matter, microbial biomass and denitrification potential in forest soils of the Northeastern United States. Appl Soil Ecol 9:197-202.

Byrne LB. 2006. Effects of urban habitat types and landscape patterns on ecological variables at the aboveground-belowground interface. Ph.D. Dissertation, Penn State University. Available online: http://etda.libraries.psu.edu/theses/approved/WorldWideFiles/ETD-1371/Final_thesis.pdf. Accessed 11 Feb 2008.

Byrne LB. 2007. Habitat structure: a fundamental concept and framework for urban soil ecology. Urban Ecosyst 10:255-74.

Byrne LB, Bruns MA. 2004. The effects of lawn management on soil microarthropods. J Agr Urban Entomol 21:150-6. 
Curry JP. 2004. Factors affecting the abundance of earthworms in soil. In: Edwards CA, Ed. Earthworm ecology. 2Boca Raton, FL: CRC Press. pp 91-1 14.

Dickenson NM, Polwart A. 1982. The effect of mowing regime on an amenity grassland ecosystem: above- and below-ground components. J Appl Ecol 19:569-77.

Fierer N, Schimel JP. 2002. Effects of drying-rewetting frequency on soil carbon and nitrogen transformations. Soil Biol Biochem 34:777-87.

Fontaine S, Berdoux G, Abbadie L, Mariotti A. 2004. Carbon input to soil may decrease soil carbon content. Ecol Lett 7:314-20.

Gallo ME, Sinasbaugh RL, Cabaniss SE. 2006. The role of ultraviolet radiation in litter decomposition in arid ecosystems. Appl Soil Ecol 34:82-91.

Gieger R, Aron RH, Todhunter P. 2003. The climate near the ground. 6th edn. Lanham, MD: Rowman and Littlefield Publishers, Inc.

Golubiewski NE. 2006. Urbanization increases grassland carbon pools: effects of landscaping in Colorado's Front Range. Ecol Appl 16:555-71.

Green DM, Oleksyszen M. 2002. Enzyme activities and carbon dioxide flux in a Sonoran desert urban ecosystem. Soil Sci Soc Am J 66:2002-8.

Grimm NB, Faeth SH, Golubiewski NE, Redman CL, Wu J, Bai X, Briggs JM. 2008. Global change and the ecology of cities. Science 319:756-60.

Holland EA, Robertson AP, Greenberg J, Groffman PM, Boone RD, Grosz JR. 1999. Soil $\mathrm{CO}_{2}, \mathrm{~N}_{2} \mathrm{O}$ and $\mathrm{CH}_{4}$ exchange. In: Robertson GP, Coleman DC, Bledsoe CS, Sollins P, Eds. Standard Soil Methods for Long-term Ecological Research. New York: Oxford University Press. pp 185-201.

Horwath WR, Paul EA. 1994. Microbial biomass. In: Weaver RW, Ed. Methods of Soil Analysis Part 2: Microbiological and Biochemical Properties. Madison, Wisconsin: Soil Science Society of America Inc. pp 753-73.

Kaye JP, Burke IC, Mosier AR, Guerschman JP. 2004. Methane and nitrous oxide flues from urban soils to the atmosphere. Ecol Appl 14:975-81.

Kaye JP, McCulley RL, Burke IC. 2005. Carbon fluxes, nitrogen cycling, and soil microbial communities in adjacent urban, native and agricultural ecosystems. Glob Chang Biol 1 1:575-97.

Kemper WD, Rosenau RC. 1986. Aggregate stability and size distribution. In: Klute A, Ed. Methods of Soil Analysis Part 1: Physical and Mineralogical Methods. 2Madison, Wisconsin, USA: Soil Science Society of America Inc. pp 425-42.

Lajtha K, Crow SE, Yano Y, Kaushal SS, Sulzman E, Sollins P, Spears JDH. 2005. Detrital controls on soil solution N and dissolved organic matter in soils: a field experiment. Biogeochemistry 76:261-81.

Landi L, Valori F, Ascher J, Renella G, Falchini L, Nannipieri P. 2006. Root exudate effects on the bacterial communities, $\mathrm{CO}_{2}$ evolution, nitrogen transformations and ATP content of rhizosphere and bulk soils. Soil Biol Biochem 38:509-16.

McCauley DJ. 2006. Selling out on nature. Nature 443:27-8.

Milesi C, Running SW, Elvidge CD, Dietz JB, Tuttle BT, Nemani RR. 2005. Mapping and modeling the biogeochemical cycling of turf grasses in the United States. Environ Manage 36: 426-38.

Montague T, Kjelgren R. 2004. Energy balance of six common landscape surfaces and the influence of surface properties on gas exchange of four containerized tree species. Sci Hortic 100:229-49.

Mueller EC, Day TA. 2005. The effect of urban ground cover on microclimate, growth and leaf gas exchange of oleander in Phoenix, Arizona. Int J Biometeorol 49:244-55.

Palmer M, Bernhardt E, Chornesky E, Collins S, Dobson A, Duke C, and others. 2004. Ecology for a crowded planet. Science 304:1251-2.

Pavao-Zuckerman MA, Coleman DC. 2005. Decomposition of chestnut oak (Quercus prinus) leaves and nitrogen mineralization in an urban environment. Biol Fertil Soils 41:343-9.

Pizl V, Schlaghamersky J. 2007. The impact of pedestrian activity on soil annelids in urban greens. Eur J Soil Biol 43:S68-71.

Pouyat RV, Carreiro MM. 2003. Controls on mass loss and nitrogen dynamics of oak leaf litter along an urban-rural landuse gradient. Oecologia 135:288-98.

Pouyat RV, Belt K, Pataki D, Groffman PM, Hom J, Band L. 2006. Effects of urban land-use change on biogeochemical cycles. In: Canadell P, Pataki D, Pitelka L, Eds. Terrestrial ecosystems in a changing world. Canberra, Australia: Springer. pp 55-78.

Pulleman MM, Six J, Uyl A, Marinissen JCY, Jongmans AG. 2005. Earthworms and management affect organic matter incorporation and microaggregate formation in agricultural soils. Appl Soil Ecol 29:1-15.

Qian Y, Follett RF. 2002. Assessing soil carbon sequestration in turfgrass systems using long-term soil testing data. Agron J 94:930-5.

Raich JW, Tufekcioglu A. 2000. Vegetation and soil respiration: correlations and controls. Biogeochemistry 48:71-90.

Scharenbroch BC, Lloyd JE, Johnson-Maynard JL. 2005. Distinguishing urban soils with physical, chemical, and biological properties. Pedobiologia 49:283-96.

Shakir SH, Dindal DL. 1997. Density and biomass of earthworms in forest and herbaceous microecosystems in central New York, North America. Soil Biol Biochem 29:275-85.

Shi W, Muruganandam S, Bowman D. 2006. Soil microbial biomass and nitrogen dynamics in a turfgrass chronosequence: a short term response to turfgrass clipping additions. Soil Biol Biochem 38:2032-42.

Shochat E, Warren PS, Faeth SH, McIntyre NE, Hope D. 2006. From population patterns to emerging processes in mechanistic urban ecology. Trends Ecol Evol 21:186-91.

Smetak KM, Johnson-Maynard JL, Lloyd JE. 2007. Earthworm population density and diversity in different-aged urban systems. Appl Soil Ecol 37:161-8.

Szlavecz K, Placella SA, Pouyat RV, Groffman PM, Csudzi C, Yesilonis I. 2006. Invasive earthworm species and nitrogen cycling in remnant forest patches. Appl Soil Ecol 32:54-62.

Vossbrink CR, Coleman DC, Wooley TA. 1979. Abiotic and biotic factors in litter decomposition in a semiarid grassland. Ecology 60:265-71. 